\title{
Corporate dividend policy practices: perceptions of financial officers of listed companies in Colombo Stock Exchange
}

\author{
Lingesiya Kengatharan \\ Department of Financial Management, University of Jaffna, Sri Lanka.
}

\begin{abstract}
Main objective of this survey was to find out the perceptions of financial officers on dividend policy practices in Sri Lanka. Current survey further extended to examine whether firm characteristics influence the corporate dividend policy practices. Stratified random sampling was used to select the 150 participants from 20 different sectors in Colombo Stock Exchange (CSE). Primary survey was carried out to collect the data using structured questionnaire in 2017 and response rate was 20\%. Cronbach' alpha was used to evaluate the reliability of the collected data. Data were analyzed by applying mean, percentage analysis and Chi-square test. Results of the survey revealed that financial managers believe that dividend payout ratio affects the market value of the firm, company willing to rescind dividend increase in the event of growth opportunities, ccompany's dividend change follows shift in long term sustainable earnings, company focuses more on absolute level of dividends than dividend changes and dividends provide signaling mechanism of the future prospects of the firm. Therefore, it was observed from the perceptions of finance professionals that dividend decisions is one of the factor affect the market value of the firm. Results of the survey further expressed that the firms characteristics: market capitalization of the firms, types of industry, educational qualification and experience of financial officers are influencing the use of certain dividend policy practices in selected firms in this survey. The survey suggested that the dividend policy is considered as very important one to the financial officers and the potential investors as it is affecting the market value of the firms. Present survey just focused on beliefs of management on dividend policy rather studying the gap between beliefs on dividend policy of management and practical application on dividend policy. Further, it should be studied that how financial officers are working with the dividend policy in order to maximize the shareholders' wealth. Keywords: dividends, dividend policy, perceptions, financial officers
\end{abstract}

\section{Introduction}

Theory of financial management is principally focusing on the three important decisions: investment, financing and dividend decisions and the interactions among them. Investment decision is mainly concerned with identification of the investment opportunities and to select the best having had better evaluation. Financial decision is primarily

concerned with making a decision of optimum capital structure of a firm, taking into account of cost, control and risk. The dividend decision is mainly concerned with the dividend decision about payment or declaration of it (Pike \& Neale, 2009). Dividend is considered as one of the unresolved problems in finance (Brealey et al., 2012). Most of the firms are frequently 
thinking of three important facts on the dividend policy: (1) how much of firm's free cash flow is to be passed to shareholders as dividend, (2) whether company is going to maintain stable dividend policy or changing policy, (3) distributions to shareholders are on the form of cash dividends or repurchasing stocks. All these facts are mostly depends on the investors' preferences on their returns. Returns of investors can be either dividend yields or capital gains. Mix of dividend yield and capital gains are determined by the firms target distribution ratio. A firm's optimal distribution policy must keep a balance between the cash dividends and capital gains so as to maximize the stock prices of firms. Therefore, setting a dividend policy is one of the most important issue in corporate finance (Subramaniyam \& Susela, 2010; Anand,2002; Panigrahi \& Zainuddin, 2015). Decision on dividend policy is not a separated one. Payment of dividend is a means of cash outflow. Therefore, it may show effect on the investment and financing decisions. Thus, dividend decisions get much concentration in finance literature.

The considerable number of studies concern field survey research to confront corporate finance theory with the practice of chief financial officers in well developed countries, particularly the USA, the UK and Europe (e.g: Graham \& Harvey, 2001; Brav et al.,2005; Brounen, de Jong \& Koedijk ,2004). But, very hard to find the studies to confront theory with the behavior of financial officers perspectives in practice in emerging countries. The present study concentrates the dividend policy practices and identifies the influences of firms' characteristics on use of dividend policy in Sri Lankan emerging market.

\section{Objectives of the study}

1. To find out the perceptions of financial officers on dividend policy practices in Sri Lanka.

2. To identify the influences of firms' characteristics on the use of dividend practices in Sri Lanka.

\section{Literature review}

There are three different theories on investors' preferences for the distribution policy of companies which can be on the form of dividend yield and capital gains.

\section{The Dividend Irrelevance Theory}

This theory discussed that there is no effect of dividend policy on either the firm's stock price or firm's cost of capital. Assumptions of this theory are no taxes, transaction cost and other market imperfection in the firms. Therefore, if there is no any considerable effect of dividend policy, then it would be considered as irrelevant (Modigliani and Miller,1961).

2. Bird in the Hand Theory: Dividends are preferred

Goldon (1959) developed the bird in the hand theory. In this theory, thoughts of the investors stand on the risk of returns and they think that risk of future capital gains are more than the dividends (Linter, 1962) . Therefore, investors prefer to have dividends and they believe that high dividend increase the share price (Robinson, 2006).

3. Tax Preference Theory: Capital Gains are Preferred

Because of the time value effects, rupees of taxes paid in the future has a less effective 
cost than rupee paid today. Therefore, the advantages of tax effect, investors may prefer to hold less dividends.

There was a famous and well known field study of dividend policy initiated by Linter (1956) in the USA. Linter analyzed that how firms are setting dividends and he identified most of the firms are giving much concern on four important facts relating to dividend: (1) long run target dividend payout policy are setting by firms, (2) long term sustainable earnings are determining factor for changes in dividend, (3) managers of the firms are giving much more concentration on changes of dividend than on fixed level, (4) generally, managers do not intend to reverse the change in dividends. Consequently , Baker and Powell (2000), Brav et al. (2005), Dhanani (2005) also explored dividend policy in the USA and the UK.

Baker and Phillips (1992) have done a survey with 121 firms. Key findings of their study suggested that firms share dividends have a significant positive psychological impact and managers of firms strongly believed that share dividend facilitate them to communicate their assurance in the firm's future prospects.

Bhat and Pandy (1994) emphasized in their study, stable dividend policy is preferred by finance managers in Indian corporations. In addition to that they have listed the dividend policy determinants: current earnings, pattern of past dividends, expected future earnings, increasing equity base and liquidity.

Anand (2002) conducted a study with 81 CFOs in India to explore capital budgeting, cost of capital, capital structure and dividend policy decisions. Major findings of the study suggested that firm management strongly believes that decisions of dividend are very essential as they present a signaling mechanism of the future prospects of the firms. Also the results suggested that the majority of the enterprises have target payout ratio and changes on dividends pursue move in the long term sustainable earnings. Isa (2008) carried out a survey on corporate finance practices in Malaysia covering the concepts of capital budgeting, capital structure and dividend policy. In terms of the dividend policy, Malaysian managers give much importance on current earnings in determining the dividends and less importance of future earnings.

Baker and Powell (2012) conducted a survey to observe the factors influencing on dividend policy. It was conducted with the perceptions of 52 firms listed on Indonesian Stock Exchange. Results of the study expressed that the steadiness of earnings, level of current and future earnings were the important determinants of dividends.

From the literature survey, concept of dividend policy in the emerging markets in general and Sri Lanka in particular has not been focused to study. Therefore, researcher can pose the research questions that

RQ1. What dividend policy practices are being applied by finance professionals in Sri Lanka RQ2.Are there any influences of firms' characteristics on the choice of dividend policy practices 


\section{Methodology}

\section{Research design}

The survey tried to evaluate the dividend policy practices from the views of finance managers of firms in Sri Lanka. Questionnaire was used to collect the data and questions on dividend policy were relatively similar to the survey in study of Anand (2002). Further, some questions were included to fit the Sri Lankan context.

\section{Data collection procedure}

Pilot survey was conducted by the researcher using self- administered questionnaire with a sample of four financial officers from different sectors with the prior arranged appointments over the phone for the pilot survey. The financial officers expressed few suggestion in order to improve the response rate and they did not express any concerns on the questionnaire.The results and the nature of the pilot study were successful and this paved the way for implementing it among 150 listed companies covering different sectors. Finally, 38 questionnaire were usable from the survey.

\section{Testing the reliability}

A reliability analysis of the item-scales was performed using SPSS. Cronbach's alpha $(\alpha)$ values were assessed for each variable with item- scales. The reliability of the measures was well above the minimum threshold of 0.60 in every case (Gliner \& Morgan, 2000). There were 13 items considered to evaluate the dividend policy practices and cronbach's alpha value was .754 . Thus, it was concluded that all of the measures were generally reliable.

\section{Data Analysis}

\section{Descriptive analysis of the survey responses}

The descriptive analyses of the survey responses are discussed under the following sub-headings.

\subsection{Educational qualification of the respondents}

Classification of the educational qualification of the respondents was grouped into: bachelor degree, MBA, non-MBA Master's, above Master's degree and professional qualification (e.g.,CIMA, ACCA). Above master degree qualification (e.g., MPhil/PhD or MBA degree with professional qualification) was held by $42.1 \%$ of CFOs, followed by MBA qualification (23.7\%), Professional qualification (21.1\%) and non-MBA Master's $(13.2 \%)$ as per table 1

Table 1: Demographic characteristics of survey respondents

$\begin{array}{lcc}\text { Educational Qualification } & \text { No. of responden1 } & \text { Percentage (\%) } \\ \text { Bachelor Degree } & (N) & - \\ \text { MBA } & - & 23.7 \\ \text { Non-MBA Masters } & 9 & 13.2 \\ \quad \text { > (above) Master Degree } & 5 & 42.1 \\ \quad \text { Professional Qualification } & 16 & 21.1 \\ \text { Market capitalization } & 8 & \\ \quad \text { <10 Billion } & 16 & 42.1\end{array}$


10-50 Billion 9

50-100 Billion $\quad 11$

100-500 Billion 2

> 500 Billon

Years of experience

$<5$ years

5-9 years

10-19 years

$>20$ years

Types of industries

Bank/Finance/ Insurance

Manufacturing Industry

Diversified Holdings

Health Care Industry

Other Non-Financial Industry

\section{Size of market capitalization}

Table 1 presents the different sizes of market capitalization. Size of market capitalization was categorized into five groups: less than LKR 10 billion, LKR 10-50 billion, LKR 50100 billion, LKR $100-500$ million and LKR 500 billion and over. The large number of financial officers reported that size of their market capitalization is less than 10 billion (42.1\%), followed by LKR 50- 100 billion (28.9\%), LKR $10-50$ Billion (23.7\%) and LKR 100-500 billion (5.3\%).

\section{Experience of the respondents}

As stated in the table 1, experience of the financial officers was classified into four groups in terms of number of years they had been in the profession: less than 5 years, 5-9 years, 10-19 years and 20 years and more. The higher number of financial officers had 10 to 19 years' experience $(N=15)$, followed by 20 years' and more experience ( $N=9$ ), 5 to 9 years' $(N=8)$ and a small number of financial officers had less than 5 years' experience $(N=6)$.
23.7

28.9

5.3

15.8

21.1

39.5

23.7

10.5

57.9

21.1

5.3

5.3

\section{Types of industry}

Types of industry were initially classified in terms of their nature (Verbeeten, 2006) as shown in table 1:

bank/ finance/ insurance industry, manufacturing industry, diversified holdings, health care industry and other non-financial industry. As can be seen in the table, 57.9\% of industries are manufacturing, followed by diversified holdings (21.1\%), bank /finance /insurance companies $(10.5 \%)$, health care industry $(5.3 \%)$ and other non-financial industry $(5.3 \%)$.

\subsection{Results and discussion}

\section{Dividend policy}

Survey responses of Sri Lankan financial officers on their company's dividend policy is presented in the table 2. Similar survey conducted by Anand (2002) in India and results are also highlighted in table 2 . 
Table 2: Survey responses for the question: your belief of your company's dividend policy.

\begin{tabular}{|c|c|c|c|c|c|c|c|}
\hline & $\begin{array}{l}\text { Strongly } \\
\text { Disagree }\end{array}$ & Disagree & Neutral & Agree & $\begin{array}{l}\text { Strongly } \\
\text { agree }\end{array}$ & $\begin{array}{l}\text { Mean \& } \\
\text { rank }\end{array}$ & $\begin{array}{l}\text { Anand } \\
\text { (2002) } \\
\text { Strongly } \\
\text { agree/ } \\
\text { disagree }\end{array}$ \\
\hline $\begin{array}{l}\text { 1) Company has a long term target } \\
\text { dividend payout ratio }\end{array}$ & $10.5 \%(4)$ & $15.8 \%(6)$ & $21.1 \%(8)$ & $36.8 \%(14)$ & $15.8 \%(6)$ & $3.3158(6)$ & 81.50 \\
\hline $\begin{array}{l}\text { 2) Company focuses more on } \\
\text { absolute level of dividends than } \\
\text { dividend changes }\end{array}$ & $5.3 \%(2)$ & $10.5 \%(4)$ & $26.3 \%(10)$ & $42.1 \%(16)$ & $15.8 \%(6)$ & $3.5263(4)$ & 67.90 \\
\hline $\begin{array}{l}\text { 3) Company's dividend change } \\
\text { follows shift in long term sustainable } \\
\text { earnings }\end{array}$ & $5.3 \%(2)$ & $10.5 \%(4)$ & $15.8 \%(6)$ & $57.9 \%(22)$ & $10.5 \%(4)$ & 3.5789 (3) & 85.20 \\
\hline $\begin{array}{l}\text { 4) Company willing to rescind } \\
\text { dividend increase in the event of } \\
\text { growth opportunities }\end{array}$ & - & $10.5 \%(4)$ & $21.1 \%(8)$ & $63.2 \%(24)$ & $5.3 \%(2)$ & $3.6316(2)$ & 56.80 \\
\hline $\begin{array}{l}\text { 5) Cash dividends as residual after } \\
\text { financing desired investments from } \\
\text { earnings }\end{array}$ & $5.3 \%(2)$ & $15.8 \%(6)$ & $36.8 \%(14)$ & $31.6 \%(12)$ & $10.5 \%(4)$ & $3.2632(7)$ & 46.90 \\
\hline $\begin{array}{l}\text { 6) Dividend payout ratio affects the } \\
\text { market value of the firm }\end{array}$ & - & $5.3 \%(2)$ & $26.3 \%(10)$ & $52.6 \%(20)$ & $15.8 \%(6)$ & 3.7895 (1) & 71.60 \\
\hline $\begin{array}{l}\text { 7) Dividends provide signaling } \\
\text { mechanism of the future prospects of } \\
\text { the firm }\end{array}$ & $5.3 \%(2)$ & $10.5 \%(4)$ & $31.6 \%(12)$ & $36.8 \%(14)$ & $15.8 \%(6)$ & $3.4737(5)$ & 71.60 \\
\hline $\begin{array}{l}\text { 8) Investors have different relative } \\
\text { risk perceptions of dividends and } \\
\text { retained earnings }\end{array}$ & $5.3 \%(2)$ & $5.3 \%(2)$ & $36.8 \%(14)$ & $36.8 \%(14)$ & $15.8 \%(6)$ & 3.5263 (4) & 64.20 \\
\hline $\begin{array}{l}\text { 9) Investors are indifferent between } \\
\text { receiving dividends and capital gains }\end{array}$ & - & $36.8 \%(14)$ & $36.8 \%(14)$ & $15.8 \%(6)$ & $10.5 \%(4)$ & $3.0000(8)$ & $(64.20)$ \\
\hline $\begin{array}{l}\text { 10) Responsive to shareholders' } \\
\text { preferences regarding dividends }\end{array}$ & - & $5.3 \%(2)$ & $52.6 \%(20)$ & $31.6(12)$ & $10.5 \%(4)$ & $3.4737(5)$ & 82.70 \\
\hline $\begin{array}{l}\text { 11) Share buyback programme should } \\
\text { replace dividend payment of the firm }\end{array}$ & $21.1 \%(8)$ & $31.6 \%(12)$ & $36.8 \%(14)$ & $5.3 \%(2)$ & $5.3 \%(2)$ & 2.4211 & $(53.10)$ \\
\hline $\begin{array}{l}\text { 12) Dividend payment subject the } \\
\text { firm to the scrutiny of the investors }\end{array}$ & $5.3 \%(2)$ & $26.3 \%(10)$ & $42.1 \%(16)$ & $21.1 \%(8)$ & $5.3 \%(2)$ & 2.9474 & (49.40) \\
\hline $\begin{array}{l}\text { 13) Dividend payments provide a } \\
\text { bonding mechanism to encourage } \\
\text { managers to Act in the best interest of } \\
\text { the shareholders }\end{array}$ & $5.3 \%(2)$ & $26.3 \%(10)$ & $47.4 \%(18)$ & $15.8 \%(6)$ & $5.3 \%(2)$ & 2.8947 & 55.60 \\
\hline
\end{tabular}

As per the results presented in the table 2, $52.6 \%$ of the respondents agreed and $15.8 \%$ of respondents strongly agreed that dividend payout ratio affects the market value of the firm $(M=3.7895)$. Further $63.2 \%$ of the International Journal of Accounting \& Business Finance respondents strongly agreed that company willing to rescind dividend increase in the event of growth opportunities $(M=3.6316)$. $57.9 \%$ of the respondents agreed and $10.5 \%$ of the respondents strongly agreed that 
ccompany's dividend change follows shift in long term sustainable earnings $(M=3.5789)$. $57.9 \%$ of the respondents strongly agreed/ agreed that company focuses more on absolute level of dividends than dividend changes $(M=$ 3.5263). Further, $52.6 \%$ of the respondents strongly agreed / agreed that dividends provide signaling mechanism of the future prospects of the firm. Again, $52.6 \%$ of the respondents strongly agreed / agreed that company has a long term target dividend payout ratio. $42.1 \%$ of the respondents strongly agreed/agreed that cash dividends as residual after financing desired investments from earnings.

Similar survey was conducted by Anand in 2002 in India and findings of his survey are in line with the current study in certain practices. E.g: $46.90 \%$ of the respondents agreed that the dividend policy is a residual decision after meeting desired needs (Anand, 2002) This findings of the study are also in line with the Linter's (1956) study.

Therefore, in order to answer the research question (1) of this survey, based on the mean values of the dividend policy concepts (above mean value 3.5 was considered as practice) following practices are being applied by financial officers in setting dividend policy in Sri Lanka. Dividend payout ratio affects the market value of the firm $(M=$ 3.7895), company willing to rescind dividend increase in the event of growth opportunities $(M=3.6316)$, ccompany's dividend change follows shift in long term sustainable earnings $(M=3.5789)$, company focuses more on absolute level of dividends than dividend changes $(M=3.5263)$, and dividends provide signaling mechanism of the future prospects of the firm (3.5). Beliefs of financial managers that dividend payout ratio affects the market value of the firm further validated by the results of the study of Harshapriya(2016). His results suggested that dividend policy has a significant impact on share price in CSE.

\section{Analysis of firm characteristics}

\section{Market capitalization and dividend policy}

$\mathrm{X}^{2}$ test has been performed to examine the relationship between size of market capitalization and application of dividend policy in Sri Lankan selected companies. Results of the $X^{2}$ test presented in the table 3 .

Table 3:Relationship between market capitalization and dividend policy

\begin{tabular}{|l|l|l|l|l|l|l|}
\hline Dividend policy (Chi Square Value) & M.Cap & Never & Rarely & Sometimes & Often & Always \\
\hline \multirow{2}{*}{$\begin{array}{l}\text { Company has a long term target } \\
\text { dividend payout ratio }\end{array}$} & $<10$ Billion & $6.2 \%$ & $12.5 \%$ & $25.0 \%$ & $43.8 \%$ & $12.5 \%$ \\
\cline { 2 - 7 } \begin{tabular}{l}
$(9.279)$ \\
\cline { 2 - 7 }
\end{tabular} & $10-50$ Billion & $22.2 \%$ & $22.2 \%$ & - & $44.4 \%$ & $11.1 \%$ \\
\cline { 2 - 7 } & $50-100$ Billion & $9.1 \%$ & $18.2 \%$ & $36.4 \%$ & $18.2 \%$ & $18.2 \%$ \\
\cline { 2 - 7 } $\begin{array}{l}\text { Company focuses more on absolute } \\
\text { level of dividends than dividend } \\
\text { changes }\end{array}$ & $100-500$ Billion & - & - & - & $50.0 \%$ & $50.0 \%$ \\
\cline { 2 - 7 }$(26.295 * *)$ & $10-50$ Billion & - & - & $55.4 \%$ & - & $44.6 \%$ \\
\cline { 2 - 7 } & $50-100$ Billion & $9.1 \%$ & $18.2 \%$ & $18.2 \%$ & $54.5 \%$ & - \\
\cline { 2 - 7 } & $100-500$ Billion & - & - & $50.0 \%$ & - & $50.0 \%$ \\
\hline
\end{tabular}




\begin{tabular}{|c|c|c|c|c|c|c|}
\hline \multirow{4}{*}{$\begin{array}{l}\text { Company's dividend change follows } \\
\text { shift in long term sustainable earning } \\
\left(29.267^{* *}\right)\end{array}$} & $<10$ Billion & - & $12.5 \%$ & - & $87.5 \%$ & - \\
\hline & 10-50 Billion & $22.2 \%$ & - & $22.2 \%$ & $22.2 \%$ & $33.3 \%$ \\
\hline & 50-100 Billion & - & $18.2 \%$ & $36.4 \%$ & $45.5 \%$ & - \\
\hline & 100-500 Billion & - & - & - & $50.0 \%$ & $50.0 \%$ \\
\hline \multirow{4}{*}{$\begin{array}{l}\text { Company willing to rescind dividend } \\
\text { increase in the event of growth } \\
\text { opportunities } \\
(12.763)\end{array}$} & $<10$ Billion & - & - & $25.0 \%$ & $75.0 \%$ & - \\
\hline & 10-50 Billion & - & $22.2 \%$ & $22.2 \%$ & $33.3 \%$ & $22.2 \%$ \\
\hline & 50-100 Billion & - & $18.2 \%$ & $18.2 \%$ & $63.6 \%$ & - \\
\hline & 100-500 Billion & - & - & - & $100.0 \%$ & - \\
\hline \multirow{4}{*}{$\begin{array}{l}\text { Cash dividends as residual after } \\
\text { financing desired investments from } \\
\text { earnings } \\
\left(26.595^{* *}\right)\end{array}$} & $<10$ Billion & - & $25.0 \%$ & $25.0 \%$ & $50.0 \%$ & - \\
\hline & 10-50 Billion & $22.2 \%$ & - & $44.4 \%$ & - & $33.3 \%$ \\
\hline & 50-100 Billion & - & $18.2 \%$ & $54.5 \%$ & $27.3 \%$ & - \\
\hline & 100-500 Billion & - & - & - & $50.0 \%$ & $50.0 \%$ \\
\hline \multirow{4}{*}{$\begin{array}{l}\text { Dividend payout ratio affects the } \\
\text { market value of the firm } \\
\text { (12.433) }\end{array}$} & $<10$ Billion & - & - & $25.0 \%$ & $43.8 \%$ & $31.2 \%$ \\
\hline & 10-50 Billion & - & - & $44.4 \%$ & $55.6 \%$ & - \\
\hline & 50-100 Billion & - & $18.2 \%$ & $18.2 \%$ & $54.5 \%$ & $9.1 \%$ \\
\hline & 100-500 Billion & - & - & - & $100.0 \%$ & - \\
\hline \multirow{4}{*}{$\begin{array}{l}\text { Dividends provide signaling } \\
\text { mechanism of the future prospects of } \\
\text { the firm } \\
(26.557 * *)\end{array}$} & $<10$ Billion & - & - & $62.5 \%$ & $25.0 \%$ & $12.5 \%$ \\
\hline & 10-50 Billion & $22.2 \%$ & $22.2 \%$ & $22.2 \%$ & $11.1 \%$ & $22.2 \%$ \\
\hline & 50-100 Billion & - & $18.2 \%$ & - & $63.6 \%$ & $18.2 \%$ \\
\hline & 100-500 Billion & - & - & - & $100 \%$ & - \\
\hline \multirow{4}{*}{$\begin{array}{l}\text { Investors have different relative risk } \\
\text { perceptions of dividends and retained } \\
\text { earnings } \\
(15.745)\end{array}$} & $<10$ Billion & - & - & $50.0 \%$ & $31.2 \%$ & $18.8 \%$ \\
\hline & 10-50 Billion & $22.2 \%$ & - & $22.2 \%$ & $44.4 \%$ & $11.1 \%$ \\
\hline & 50-100 Billion & - & $18.2 \%$ & $36.4 \%$ & $36.4 \%$ & $9.1 \%$ \\
\hline & 100-500 Billion & - & - & - & $50.0 \%$ & $50.0 \%$ \\
\hline \multirow{4}{*}{$\begin{array}{l}\text { Investors are indifferent between } \\
\text { receiving dividends and capital gains } \\
(14.137)\end{array}$} & $<10$ Billion & - & $25.0 \%$ & $37.5 \%$ & $25.0 \%$ & $12.5 \%$ \\
\hline & 10-50 Billion & - & $22.2 \%$ & $66.7 \%$ & - & $11.1 \%$ \\
\hline & 50-100 Billion & - & $63.6 \%$ & $18.2 \%$ & $18.2 \%$ & - \\
\hline & 100-500 Billion & - & $50.0 \%$ & - & - & $50.0 \%$ \\
\hline \multirow{4}{*}{$\begin{array}{l}\text { Responsive to shareholders' } \\
\text { preferences regarding dividends } \\
\text { (15.322) }\end{array}$} & $<10$ Billion & - & - & $50.0 \%$ & $50.0 \%$ & - \\
\hline & 10-50 Billion & - & $22.2 \%$ & $44.4 \%$ & $22.2 \%$ & $11.1 \%$ \\
\hline & 50-100 Billion & - & - & $63.6 \%$ & $18.2 \%$ & $18.2 \%$ \\
\hline & 100-500 Billion & - & - & $50.0 \%$ & - & $50.0 \%$ \\
\hline \multirow{4}{*}{$\begin{array}{l}\text { Share buyback programme should } \\
\text { replace dividend payment of the firm } \\
(18.955)\end{array}$} & $<10$ Billion & $18.8 \%$ & $37.5 \%$ & $31.2 \%$ & - & $12.5 \%$ \\
\hline & 10-50 Billion & $33.3 \%$ & $22.2 \%$ & $44.4 \%$ & - & - \\
\hline & 50-100 Billion & - & $36.4 \%$ & $45.5 \%$ & $18.2 \%$ & - \\
\hline & 100-500 Billion & $100.0 \%$ & - & - & - & - \\
\hline
\end{tabular}




\begin{tabular}{|l|l|l|l|l|l|l|}
\hline \multirow{2}{*}{$\begin{array}{l}\text { Dividend payment subject the firm to } \\
\text { the scrutiny of the investors }\end{array}$} & $<10$ Billion & - & $25.0 \%$ & $37.5 \%$ & $25.0 \%$ & $12.5 \%$ \\
\cline { 2 - 8 } \begin{tabular}{l}
$(18.109)$ \\
\cline { 2 - 8 }
\end{tabular} & $10-50$ Billion & $11.1 \%$ & $44.4 \%$ & $44.4 \%$ & - & - \\
\cline { 2 - 8 } & $50-100$ Billion & - & $18.2 \%$ & $45.5 \%$ & $36.4 \%$ & - \\
\hline $\begin{array}{l}\text { Dividend payments provide a bondin } \\
\text { mechanism to encourage managers to } \\
\text { Act in the best interest of the } \\
\text { shareholders } \\
(15.388)\end{array}$ & $<10$ Billion & $12.5 \%$ & $6.2 \%$ & $43.8 \%$ & $25.0 \%$ & $12.5 \%$ \\
\cline { 2 - 8 } & $10-50$ Billion & - & $44.4 \%$ & $55.6 \%$ & - & - \\
\cline { 2 - 8 } & $50-100$ Billion & - & $45.5 \%$ & $36.4 \%$ & $18.2 \%$ & - \\
\cline { 2 - 8 } & $100-500$ Billion & - & - & $100.0 \%$ & - & - \\
\hline
\end{tabular}

$* *$ is $\chi 2$ significant within the specific dividend policy at the .01 level,

$*$ is $\chi^{2}$ significant within the specific dividend policy at the .05 level,

As per the results presented in table 3, value of Chi-square test was significant for the selected dividend policy concepts: company focuses more on absolute level of dividends than changes, company's dividend change follows shift in long term sustainable earnings, cash dividends as residual after financing desired investments from earnings and dividend provide signaling mechanism of the future prospects of the firm $(p<.05)$. It was observed that the firms with large market capitalization (100-500 billion) were more inclined to use of them. Therefore, it can be concluded that companies with the large market capitalization were preferred to use the dividend policy in terms of company focuses more on absolute level of dividends than dividend changes, company's dividend change follows shift in long term sustainable earnings, cash dividends as residual after financing desired investments from earnings and dividend provide signaling mechanism of the future prospects of the firm.

\section{Types of industry and dividend policy}

Again it was tested that relationship between types of industry and practices of dividend policy by performing $\chi^{2}$ test and results presented in the table 4 .

Table 4: Relationship between types of industry and dividend policy

\begin{tabular}{|l|l|c|c|c|c|c|}
\hline $\begin{array}{c}\text { Capital structure } \\
\text { (Chi Square Value) }\end{array}$ & \multicolumn{1}{|c|}{ Type of industry } & Never & Rarely & $\begin{array}{c}\text { Some } \\
\text { times }\end{array}$ & Often & Always \\
\hline $\begin{array}{l}\text { Company has a long term target } \\
\text { dividend payout ratio } \\
\left(37.095^{* *}\right)\end{array}$ & Bank/Finance/ & - & $50 \%$ & - & - & $50 \%$ \\
\cline { 2 - 7 } & Manufacturing & $18.2 \%$ & $9.1 \%$ & $27.3 \%$ & $36.4 \%$ & $9.1 \%$ \\
\cline { 2 - 8 } & Diversified Holdings & - & - & - & $75 \%$ & $25 \%$ \\
\cline { 2 - 7 } & Health Care Industry & - & - & $100 \%$ & - & - \\
\cline { 2 - 8 } & Other Non-Financial & - & $100 \%$ & - & - & - \\
\hline $\begin{array}{l}\text { Company focuses more on } \\
\text { absolute level of dividends than }\end{array}$ & Bank/Finance/ & - & - & $50 \%$ & $50 \%$ & - \\
\cline { 2 - 8 } & Manufacturing & $9.1 \%$ & $9.1 \%$ & $9.1 \%$ & $45.5 \%$ & $27.3 \%$ \\
\hline
\end{tabular}




\begin{tabular}{|c|c|c|c|c|c|c|}
\hline \multirow[t]{3}{*}{ dividend changes $(37.244 * *)$} & Diversified Holdings & - & - & $75 \%$ & $25 \%$ & - \\
\hline & Health Care Industry & - & - & - & $100 \%$ & - \\
\hline & Other Non-Financial & - & $100 \%$ & - & - & - \\
\hline \multirow{5}{*}{$\begin{array}{l}\text { Company's dividend change } \\
\text { follows shift in long term } \\
\text { sustainable earnings } \\
\left(44.176^{* *}\right)\end{array}$} & Bank/Finance/ & - & - & - & $100 \%$ & - \\
\hline & Manufacturing & $9.1 \%$ & $9.1 \%$ & - & $63.6 \%$ & $18.2 \%$ \\
\hline & Diversified Holdings & - & - & $50 \%$ & $50 \%$ & - \\
\hline & Health Care Industry & - & - & $100 \%$ & - & - \\
\hline & Other Non-Financial & - & $100 \%$ & - & - & - \\
\hline \multirow{5}{*}{$\begin{array}{l}\text { Company willing to rescind } \\
\text { dividend increase in the event of } \\
\text { growth opportunities }(33.250 * *)\end{array}$} & Bank/Finance/ & - & $50 \%$ & - & $50 \%$ & - \\
\hline & Manufacturing & - & - & $18.2 \%$ & $72.7 \%$ & $9.1 \%$ \\
\hline & Diversified Holdings & - & - & $50 \%$ & $50 \%$ & - \\
\hline & Health Care Industry & - & - & - & $100 \%$ & - \\
\hline & Other Non-Financial & - & $100 \%$ & - & - & - \\
\hline \multirow{5}{*}{$\begin{array}{l}\text { Cash dividends as residual after } \\
\text { financing desired investments } \\
\text { from earnings } \\
\left(38.740^{* *}\right)\end{array}$} & Bank/Finance/ & $50 \%$ & - & $50 \%$ & - & - \\
\hline & Manufacturing & - & $18.2 \%$ & $27.3 \%$ & $36.4 \%$ & $18.2 \%$ \\
\hline & Diversified Holdings & - & - & $50 \%$ & $50 \%$ & - \\
\hline & Health Care Industry & - & - & $100 \%$ & - & - \\
\hline & Other Non-Financial & - & $100 \%$ & - & - & - \\
\hline \multirow{5}{*}{$\begin{array}{l}\text { Dividend payout ratio affects the } \\
\text { market value of the firm } \\
(45.542 * *)\end{array}$} & Bank/Finance/ & - & - & - & $50 \%$ & $50 \%$ \\
\hline & Manufacturing & - & - & $36.4 \%$ & $54.5 \%$ & $9.1 \%$ \\
\hline & Diversified Holdings & - & - & $25 \%$ & $50 \%$ & $25 \%$ \\
\hline & Health Care Industry & - & - & - & $100 \%$ & - \\
\hline & Other Non-Financial & - & $100 \%$ & - & - & - \\
\hline \multirow{5}{*}{$\begin{array}{l}\text { Dividends provide signalling } \\
\text { mechanism of the future } \\
\text { prospects of the firm }(50.502 * *)\end{array}$} & Bank/Finance/ & $50 \%$ & - & - & - & $50 \%$ \\
\hline & Manufacturing & - & - & $45.5 \%$ & $45.5 \%$ & $9.1 \%$ \\
\hline & Diversified Holdings & - & $25 \%$ & $25 \%$ & $25 \%$ & 255 \\
\hline & Health Care Industry & - & - & - & $100 \%$ & - \\
\hline & Other Non-Financial & - & $100 \%$ & - & - & - \\
\hline \multirow{5}{*}{$\begin{array}{l}\text { Investors have different relative } \\
\text { risk perceptions of dividends and } \\
\text { retained earnings } \\
\left(66.459^{* *}\right)\end{array}$} & Bank/Finance/ & $50 \%$ & - & - & - & $50 \%$ \\
\hline & Manufacturing & - & - & $36.4 \%$ & $45.5 \%$ & $18.2 \%$ \\
\hline & Diversified Holdings & - & - & $50 \%$ & $50 \%$ & - \\
\hline & Health Care Industry & - & - & $100 \%$ & - & - \\
\hline & Other Non-Financial & - & $100 \%$ & - & - & - \\
\hline \multirow{5}{*}{$\begin{array}{l}\text { Investors are indifferent between } \\
\text { receiving dividends and capital } \\
\text { gains } \\
(25.292 *)\end{array}$} & Bank/Finance/ & - & - & $50 \%$ & - & $50 \%$ \\
\hline & Manufacturing & - & $36.4 \%$ & $36.4 \%$ & $18.2 \%$ & $9.1 \%$ \\
\hline & Diversified Holdings & - & $50 \%$ & $50 \%$ & - & - \\
\hline & Health Care Industry & - & - & - & $100 \%$ & - \\
\hline & Other Non-Financial & - & $100 \%$ & - & - & - \\
\hline \multirow{5}{*}{$\begin{array}{l}\text { Responsive to shareholders' } \\
\text { preferences regarding dividends } \\
(22.800 *)\end{array}$} & Bank/Finance/ & - & - & $50 \%$ & $50 \%$ & - \\
\hline & Manufacturing & - & $9.1 \%$ & $54.5 \%$ & $27.3 \%$ & $9.1 \%$ \\
\hline & Diversified Holdings & - & - & $50 \%$ & $50 \%$ & - \\
\hline & Health Care Industry & - & - & $100 \%$ & - & - \\
\hline & Other Non-Financial & - & - & - & - & $100 \%$ \\
\hline
\end{tabular}




\begin{tabular}{|c|c|c|c|c|c|c|}
\hline \multirow{4}{*}{$\begin{array}{l}\text { Share buyback programme } \\
\text { should replace dividend payment } \\
\text { of the firm } \\
\left(62.315^{* *)}\right.\end{array}$} & Bank/Finance/ & - & - & $50 \%$ & - & $50 \%$ \\
\hline & Diversified Holdings & $25 \%$ & $25 \%$ & $50 \%$ & - & - \\
\hline & Health Care Industry & - & - & - & $100 \%$ & - \\
\hline & Other Non-Financial & - & $100 \%$ & - & - & - \\
\hline \multirow{3}{*}{$\begin{array}{l}\text { Dividend payment subject the } \\
\text { firm to the scrutiny of the } \\
\text { investors }(34.848 * *)\end{array}$} & Manufacturing & $9.1 \%$ & $36.4 \%$ & $36.4 \%$ & $18.2 \%$ & - \\
\hline & Diversified Holdings & - & - & $50 \%$ & $50 \%$ & - \\
\hline & Health Care Industry & - & - & $100 \%$ & - & - \\
\hline \multirow{4}{*}{$\begin{array}{l}\text { Dividend payments provide a } \\
\text { bonding mechanism to } \\
\text { encourage managers to act in the } \\
\text { best interest of shareholders } \\
(35.198 * *)\end{array}$} & Manufacturing & $9.1 \%$ & $27.3 \%$ & $54.5 \%$ & $9.1 \%$ & - \\
\hline & Diversified Holdings & - & $25 \%$ & $25 \%$ & $50 \%$ & - \\
\hline & Health Care Industry & - & - & $100 \%$ & - & - \\
\hline & Other Non-Financial & - & $100 \%$ & - & - & - \\
\hline
\end{tabular}

$* *$ is $\chi^{2}$ significant within the specific dividend policy at the .01 level,

$*$ is $\chi 2$ significant within the specific dividend policy at the .05 level,

As per the results presented in table 4 , value of industry groups are significantly differ in Chi-square test was significant for all the setting dividend policy .

dividend policy concept considered in this study $(p<.05)$. It was observed that types of

\section{Educational qualification and experience of financial officers and dividend policy}

Table 5:Relationship between educational qualification and dividend policy

\begin{tabular}{|c|c|c|c|c|c|c|}
\hline $\begin{array}{l}\text { Dividend policy } \\
\text { (Chi Square Value) }\end{array}$ & Educational qualification & Never & Rarely & Sometimes & Often & Always \\
\hline \multirow{4}{*}{$\begin{array}{l}\text { Company has a long term } \\
\text { target dividend payout ratio } \\
\left(18.598^{*}\right)\end{array}$} & MBA & $11.1 \%$ & $22.2 \%$ & $33.3 \%$ & $33.3 \%$ & - \\
\hline & Non-MBA Masters & $40.0 \%$ & $20.0 \%$ & - & $40.0 \%$ & - \\
\hline & $>$ (above) Master Degree & - & $6.2 \%$ & $18.8 \%$ & $56.2 \%$ & $18.8 \%$ \\
\hline & Professional Qualification & $12.5 \%$ & $25.0 \%$ & $25.0 \%$ & - & $37.5 \%$ \\
\hline \multirow{4}{*}{$\begin{array}{l}\text { Company focuses more on } \\
\text { absolute level of dividends than } \\
\text { dividend changes } \\
\left(23.241^{* *}\right)\end{array}$} & MBA & $11.1 \%$ & $22.2 \%$ & $22.2 \%$ & $33.3 \%$ & $11.1 \%$ \\
\hline & Non-MBA Masters & - & $20.0 \%$ & $20.0 \%$ & & $60.0 \%$ \\
\hline & $>$ (above) Master Degree & - & $6.2 \%$ & $43.8 \%$ & $37.5 \%$ & $12.5 \%$ \\
\hline & Professional Qualification & $12.5 \%$ & - & - & $87.5 \%$ & - \\
\hline \multirow{4}{*}{$\begin{array}{l}\text { Company's dividend change } \\
\text { follows shift in long term } \\
\text { sustainable earnings } \\
(24.911 * * *)\end{array}$} & MBA & - & $22.2 \%$ & $11.1 \%$ & $55.6 \%$ & $11.1 \%$ \\
\hline & Non-MBA Masters & $40.0 \%$ & $20.0 \%$ & $20.0 \%$ & - & $20.0 \%$ \\
\hline & $>$ (above) Master Degree & - & $6.2 \%$ & $25.0 \%$ & $56.2 \%$ & $12.5 \%$ \\
\hline & Professional Qualification & - & - & - & $100.0 \%$ & - \\
\hline \multirow{3}{*}{$\begin{array}{l}\text { Company willing to rescind } \\
\text { dividend increase in the event } \\
\text { of growth opportunities } \\
\left(27.768^{* *}\right)\end{array}$} & MBA & - & $22.2 \%$ & $44.4 \%$ & $33.3 \%$ & - \\
\hline & Non-MBA Masters & - & $20.0 \%$ & $20.0 \%$ & $20.0 \%$ & $40.0 \%$ \\
\hline & $>$ (above) Master Degree & - & $6.2 \%$ & - & $93.8 \%$ & - \\
\hline
\end{tabular}




\begin{tabular}{|c|c|c|c|c|c|c|}
\hline & Professional Qualification & - & - & $37.5 \%$ & $62.5 \%$ & - \\
\hline \multirow{4}{*}{$\begin{array}{l}\text { Cash dividends as residual after } \\
\text { financing desired investments } \\
\text { from earnings } \\
(13.715)\end{array}$} & MBA & $11.1 \%$ & $22.2 \%$ & $44.4 \%$ & $22.2 \%$ & - \\
\hline & Non-MBA Masters & - & $20.0 \%$ & $40.0 \%$ & - & $40.0 \%$ \\
\hline & $>$ (above) Master Degree & $6.2 \%$ & $6.2 \%$ & $25.0 \%$ & $50.0 \%$ & $12.5 \%$ \\
\hline & Professional Qualification & - & $25.0 \%$ & $50.0 \%$ & $25.0 \%$ & - \\
\hline \multirow{4}{*}{$\begin{array}{l}\text { Dividend payout ratio affects } \\
\text { the market value of the firm } \\
(14.257)\end{array}$} & MBA & - & $11.1 \%$ & $44.4 \%$ & $33.3 \%$ & $11.1 \%$ \\
\hline & Non-MBA Masters & - & $20.0 \%$ & $60.0 \%$ & $20.0 \%$ & - \\
\hline & $>$ (above) Master Degree & - & - & $6.2 \%$ & $75.0 \%$ & $18.8 \%$ \\
\hline & Professional Qualification & - & - & $25.0 \%$ & $50.0 \%$ & $25.0 \%$ \\
\hline \multirow{4}{*}{$\begin{array}{l}\text { Dividends provide signalling } \\
\text { mechanism of the future } \\
\text { prospects of the firm } \\
(17.026)\end{array}$} & MBA & $11.1 \%$ & $22.2 \%$ & $44.4 \%$ & $22.2 \%$ & - \\
\hline & Non-MBA Masters & - & $40.0 \%$ & $20.0 \%$ & - & $40.0 \%$ \\
\hline & $>$ (above) Master Degree & $6.2 \%$ & - & $25.0 \%$ & $50.0 \%$ & $18.8 \%$ \\
\hline & Professional Qualification & - & - & $37.5 \%$ & $50.0 \%$ & $12.5 \%$ \\
\hline \multirow{4}{*}{$\begin{array}{l}\text { Investors have different relative } \\
\text { risk perceptions of dividends } \\
\text { and retained earnings } \\
(12.496)\end{array}$} & MBA & $11.1 \%$ & $11.1 \%$ & $44.4 \%$ & $22.2 \%$ & $11.1 \%$ \\
\hline & Non-MBA Masters & $-\%$ & $20.0 \%$ & $20.0 \%$ & $60.0 \%$ & - \\
\hline & $>$ (above) Master Degree & $6.2 \%$ & - & $25.0 \%$ & $50.0 \%$ & $18.8 \%$ \\
\hline & Professional Qualification & - & - & $62.5 \%$ & $12.5 \%$ & $25.0 \%$ \\
\hline \multirow{4}{*}{ 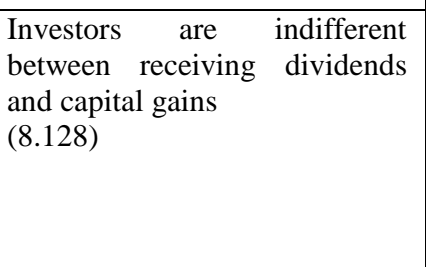 } & MBA & - & $22.2 \%$ & $55.6 \%$ & $22.2 \%$ & - \\
\hline & Non-MBA Masters & - & $60.0 \%$ & $40.0 \%$ & - & - \\
\hline & $>$ (above) Master Degree & - & $43.8 \%$ & $18.8 \%$ & $18.8 \%$ & $18.8 \%$ \\
\hline & Professional Qualification & - & $25.0 \%$ & $50.0 \%$ & $12.5 \%$ & $12.5 \%$ \\
\hline \multirow{4}{*}{$\begin{array}{lrr}\text { Responsive } & \text { to } & \text { shareholders' } \\
\text { preferences } & & \text { regarding } \\
\text { dividends } & & \\
\left(18.835^{* *}\right) & & \end{array}$} & MBA & - & - & $44.4 \%$ & $44.4 \%$ & $11.1 \%$ \\
\hline & Non-MBA Masters & - & $40.0 \%$ & $20.0 \%$ & $20.0 \%$ & $20.0 \%$ \\
\hline & $>$ (above) Master Degree & - & - & $68.8 \%$ & $18.8 \%$ & $12.5 \%$ \\
\hline & Professional Qualification & - & - & $50.0 \%$ & $50.0 \%$ & - \\
\hline \multirow{4}{*}{$\begin{array}{l}\text { Share buyback programme } \\
\text { should replace } \\
\text { payment of the firm } \\
\text { (17.592) }\end{array}$} & MBA & - & $33.3 \%$ & $66.7 \%$ & - & - \\
\hline & Non-MBA Masters & $40.0 \%$ & $40.0 \%$ & $20.0 \%$ & - & - \\
\hline & $>$ (above) Master Degree & $37.5 \%$ & $31.2 \%$ & $12.5 \%$ & $12.5 \%$ & $6.2 \%$ \\
\hline & Professional Qualification & - & $25.0 \%$ & $62.5 \%$ & - & $12.5 \%$ \\
\hline \multirow{4}{*}{$\begin{array}{l}\text { Dividend payment subject the } \\
\text { firm to the scrutiny of the } \\
\text { investors } \\
(16.791)\end{array}$} & MBA & - & $33.3 \%$ & $55.6 \%$ & $11.1 \%$ & - \\
\hline & Non-MBA Masters & - & $80.0 \%$ & $20.0 \%$ & - & - \\
\hline & $>$ (above) Master Degree & $12.5 \%$ & $6.2 \%$ & $50.0 \%$ & $25.0 \%$ & $6.2 \%$ \\
\hline & Professional Qualification & - & $25.0 \%$ & $25.0 \%$ & $37.5 \%$ & $12.5 \%$ \\
\hline \multirow{4}{*}{$\begin{array}{l}\text { Dividend payments provide a } \\
\text { bonding mechanism to } \\
\text { encourage managers to Act in } \\
\text { the best interest of the } \\
\text { shareholders } \\
(26.433 * * *)\end{array}$} & MBA & - & $33.3 \%$ & $55.6 \%$ & $11.1 \%$ & - \\
\hline & Non-MBA Masters & - & $80.0 \%$ & $20.0 \%$ & - & - \\
\hline & $>$ (above) Master Degree & - & - & $62.5 \%$ & $31.2 \%$ & $6.2 \%$ \\
\hline & Professional Qualification & $25.0 \%$ & $37.5 \%$ & $25.0 \%$ & - & $12.5 \%$ \\
\hline
\end{tabular}

** is $\chi^{2}$ significant within the specific dividend policy at the .01 level,

$*$ is $\chi^{2}$ significant within the specific dividend policy at the .05 level, 
As per the results presented in table 5, value of Chi-square test was significant for company has long term target dividend payout ratio, company focuses more on absolute level of dividends than changes, company's dividend change follows shift in long term sustainable earnings, willing to rescind dividend increase in the event of growth opportunities, responsive to shareholders' preferences regarding dividends, and dividend payments provide a bonding mechanism to encourage managers to act in best interest of the shareholders $(p<.05)$. it was observed that the firms' financial officers with Non MBA masters were more intend to use the dividend policy that focuses more on absolute level of dividends than changes. However, firms' financial officers with the above master degree qualifications and with the professional qualifications were significantly inclined to use the dividend policies that company has long term target dividend payout ratio, company's dividend change follows shift in long term sustainable earnings, willing to rescind dividend increase in the event of growth opportunities, responsive to shareholders' preferences regarding dividends, and dividend payments provide a bonding mechanism to encourage managers to act in best interest of the shareholders.

Table 6:Relationship between experience and dividend policy

\begin{tabular}{|c|c|c|c|c|c|c|}
\hline Dividend policy (Chi Square Value) & Experience & Never & Rarely & $\begin{array}{l}\text { Some } \\
\text { times }\end{array}$ & Often & Always \\
\hline \multirow{4}{*}{$\begin{array}{l}\text { Company has a long term target dividend } \\
\text { payout ratio } \\
\left(28.241^{* *}\right)\end{array}$} & $<5$ years & - & $50 \%$ & - & $33.3 \%$ & $16.7 \%$ \\
\hline & $5-9$ years & $50 \%$ & - & $25 \%$ & $25 \%$ & - \\
\hline & $10-19$ & - & $13.3 \%$ & $13.3 \%$ & $46.7 \%$ & $26.7 \%$ \\
\hline & $>20$ years & - & $11.1 \%$ & $44.4 \%$ & $33.3 \%$ & $11.1 \%$ \\
\hline \multirow{4}{*}{$\begin{array}{l}\text { Company focuses more on absolute level of } \\
\text { dividends than dividend changes } \\
\left(22.438^{* *}\right)\end{array}$} & $<5$ years & - & $33.3 \%$ & $50 \%$ & $16.7 \%$ & - \\
\hline & $5-9$ years & $25 \%$ & $25 \%$ & - & $25 \%$ & $25 \%$ \\
\hline & $10-19$ & - & - & $26.7 \%$ & $60 \%$ & $13.3 \%$ \\
\hline & $>20$ years & - & - & $33.3 \%$ & $44.4 \%$ & $22.2 \%$ \\
\hline \multirow{4}{*}{$\begin{array}{l}\text { Company's dividend change follows shift in } \\
\text { long term sustainable earnings } \\
\left(24.575^{*}\right)\end{array}$} & $<5$ years & - & $33.3 \%$ & $33.3 \%$ & $33.3 \%$ & - \\
\hline & $5-9$ years & $25 \%$ & $25 \%$ & - & $50 \%$ & - \\
\hline & $10-19$ & - & - & $6.7 \%$ & $80 \%$ & $13.3 \%$ \\
\hline & $>20$ years & - & - & $33.3 \%$ & $44.4 \%$ & 22.25 \\
\hline \multirow{4}{*}{$\begin{array}{l}\text { Company willing to rescind dividend } \\
\text { increase in the event of growth opportunities } \\
\left(28.922^{* *}\right)\end{array}$} & $<5$ years & - & $50 \%$ & $50 \%$ & - & - \\
\hline & $5-9$ years & - & - & $25 \%$ & $50 \%$ & $25 \%$ \\
\hline & $10-19$ & - & - & $6.7 \%$ & $93.3 \%$ & - \\
\hline & $>20$ years & - & $11.1 \%$ & $22.2 \%$ & $66.7 \%$ & - \\
\hline \multirow{4}{*}{$\begin{array}{l}\text { Cash dividends as residual after financing } \\
\text { desired investments from earnings } \\
(12.265)\end{array}$} & $<5$ years & $16.7 \%$ & $33.3 \%$ & $50 \%$ & - & - \\
\hline & $5-9$ years & - & $25 \%$ & $25 \%$ & $25 \%$ & $25 \%$ \\
\hline & $10-19$ & - & $13.3 \%$ & $40 \%$ & $40 \%$ & $6.7 \%$ \\
\hline & $>20$ years & $11.1 \%$ & - & $33.3 \%$ & $44.4 \%$ & $11.1 \%$ \\
\hline \multirow[t]{2}{*}{ Dividend payout ratio affects the market } & $<5$ years & - & $33.3 \%$ & $33.3 \%$ & $33.3 \%$ & - \\
\hline & $5-9$ years & - & - & $50 \%$ & $25 \%$ & $25 \%$ \\
\hline
\end{tabular}




\begin{tabular}{|c|c|c|c|c|c|c|}
\hline \multirow{2}{*}{$\begin{array}{l}\text { value of the firm } \\
\left(21.255^{*}\right)\end{array}$} & $10-19$ & - & - & $6.7 \%$ & $66.7 \%$ & $26.7 \%$ \\
\hline & $>20$ years & - & - & $33.3 \%$ & $66.7 \%$ & - \\
\hline \multirow{4}{*}{$\begin{array}{l}\text { 5Dividends provide signaling mechanism of } \\
\text { the future prospects of the firm } \\
\left(30.485^{* *}\right)\end{array}$} & $<5$ years & $16.7 \%$ & $66.7 \%$ & - & $16.7 \%$ & - \\
\hline & $5-9$ years & - & - & $25 \%$ & $50 \%$ & $25 \%$ \\
\hline & $10-19$ & - & - & $46.7 \%$ & $40 \%$ & $13.3 \%$ \\
\hline & $>20$ years & $11.1 \%$ & - & $33.3 \%$ & $33.3 \%$ & $22.2 \%$ \\
\hline \multirow{4}{*}{$\begin{array}{l}\text { Investors have different relative risk } \\
\text { perceptions of dividends and retained } \\
\text { earnings } \\
(19.040)\end{array}$} & $<5$ years & $16.7 \%$ & $33.3 \%$ & $50 \%$ & - & - \\
\hline & $5-9$ years & - & - & $25 \%$ & $50 \%$ & $25 \%$ \\
\hline & $10-19$ & - & - & $40 \%$ & $40 \%$ & $20 \%$ \\
\hline & $>20$ years & $11.1 \%$ & - & $33.3 \%$ & $44.4 \%$ & $11.1 \%$ \\
\hline \multirow{4}{*}{$\begin{array}{l}\text { Investors are indifferent between receiving } \\
\text { dividends and capital gains } \\
(9.470)\end{array}$} & $<5$ years & - & $33.3 \%$ & $66.7 \%$ & - & - \\
\hline & $5-9$ years & - & $50 \%$ & $25 \%$ & $25 \%$ & - \\
\hline & $10-19$ & - & $33.3 \%$ & $40 \%$ & $6.7 \%$ & $20 \%$ \\
\hline & $>20$ years & - & $33.3 \%$ & $22.2 \%$ & $33.3 \%$ & $11.1 \%$ \\
\hline \multirow{4}{*}{$\begin{array}{l}\text { Responsive to shareholders' preferences } \\
\text { regarding dividends } \\
(12.434)\end{array}$} & $<5$ years & - & - & $50 \%$ & $16.7 \%$ & $33.3 \%$ \\
\hline & $5-9$ years & - & $25 \%$ & $50 \%$ & $25 \%$ & - \\
\hline & $10-19$ & - & - & $53.3 \%$ & $40 \%$ & $6.7 \%$ \\
\hline & $>20$ years & - & - & $55.6 \%$ & $33.3 \%$ & $11.1 \%$ \\
\hline \multirow{4}{*}{$\begin{array}{l}\text { Share buyback programme should replace } \\
\text { dividend payment of the firm } \\
\text { (11.619) }\end{array}$} & $<5$ years & - & $33.3 \%$ & $66.7 \%$ & - & - \\
\hline & $5-9$ years & $25 \%$ & $25 \%$ & $50 \%$ & - & - \\
\hline & $10-19$ & $33.3 \%$ & $33.3 \%$ & $13.3 \%$ & $6.7 \%$ & $13.3 \%$ \\
\hline & $>20$ years & $11.1 \%$ & $33.3 \%$ & $44.4 \%$ & $11.1 \%$ & - \\
\hline \multirow{4}{*}{$\begin{array}{l}\text { Dividend payment subject the firm to the } \\
\text { scrutiny of the investors } \\
\text { (11.754) }\end{array}$} & $<5$ years & - & $33.3 \%$ & $50 \%$ & $16.7 \%$ & - \\
\hline & $5-9$ years & - & $50 \%$ & $50 \%$ & - & - \\
\hline & $10-19$ & $6.7 \%$ & $20 \%$ & $40 \%$ & $20 \%$ & $13.3 \%$ \\
\hline & $>20$ years & $11.1 \%$ & $11.1 \%$ & $33.3 \%$ & $44.4 \%$ & - \\
\hline \multirow{4}{*}{$\begin{array}{l}\text { Dividend payments provide a bonding } \\
\text { mechanism to encourage managers to Act in } \\
\text { the best interest of the shareholders } \\
(14.102)\end{array}$} & $<5$ years & - & $50 \%$ & $50 \%$ & - & - \\
\hline & $5-9$ years & - & $50 \%$ & $25 \%$ & $25 \%$ & - \\
\hline & $10-19$ & $13.3 \%$ & $13.3 \%$ & $46.7 \%$ & $13.3 \%$ & $13.3 \%$ \\
\hline & $>20$ years & - & $11.1 \%$ & $66.7 \%$ & $22.2 \%$ & - \\
\hline
\end{tabular}

$* *$ is $\chi 2$ significant within the specific dividend policy at the .01 level,

$*$ is $\chi 2$ significant within the specific dividend policy at the .05 level,

In order to evaluate the relationship between experience of financial offices and dividend policy Chi-square test was performed and the results presented in table 6. As per the results, value of
Chi-square test was significant for company has long term target dividend payout ratio, company focuses more on absolute level of dividends than changes, company's dividend change follows shift 
in long term sustainable earnings, willing to rescind dividend increase in the event of growth opportunities, company's dividend payout ratio affects the market value of the firm and company's dividends provide signaling mechanism of the future prospects of the firm. These findings expressed that financial officers are with the more experience were preferred to use above dividend policy practices in the firms.

\section{Conclusion}

The present survey evaluates the perceptions of finance managers on dividend policy practices of selected firms listed in CSE. There are 150 firms selected for this survey. Primary survey was conducted to collect the data and then survey was finally concluded with 38 responses from financial officers of companies listed in CSE. Results of the survey disclosed that financial managers belief that dividend payout ratio affects the market value of the firm, company willing to rescind dividend increase in the event of growth opportunities, ccompany's dividend change follows shift in long term sustainable earnings, company focuses more on absolute level of dividends than dividend changes and dividends provide signaling mechanism of the future prospects of the firm. Therefore, it was observed from the perceptions of financial officers that dividend decisions is one of the factor affect the market value of the firm. Results of the survey further expressed that the size of market capitalization of the firms, types of industry, educational qualification and experience of financial officers are influencing the use of certain dividend policy practices in selected firms in this survey. Present survey just focused on perceptions of management views on dividend policy rather studying the gap between beliefs on dividend policy of management and practical application on dividend policy. Further, it should be studied that how financial managers are working with the dividend policy in order to maximize the shareholders' wealth.

\section{References}

Anand, M. (2002). Corporate finance practices in India: a survey. Vikalpa,27(4), 29-56.

Baker, H., \& Powell, G. (2000). Determinants of corporate dividend policy: A survey of NYSE firms. Financial practice \& education, 10(1), 29-40.

Baker, H. K., \& Phillips, A. L. (1992). Managements' views on stock dividends. Working Paper Series, 1-27.

Baker, K., \& Powell, G. E. (2012). Dividend policy in Indonesia: survey evidence from executives. Journal of Asia Business Studies, 6(1).79-92.

Bhat, R., \& Pandey, I. M. (1994). Dividend decision: A study of managers' perceptions, Decision, 21(1\&2), 67-86.

Brav, A., Graham, J. R., Harvey, C.R., \& Michaely, R. (2005). Payout policy in the 21st century, Journal of Financial Economics, 77 (1), 483-527.

Brealey, R. A., Myers, S. C., Allen, F., \& Mohanty, P. (2012). Principles of corporate finance. $10^{\text {th }}$ edn., Tata McGraw-Hill Education Private Limited, New Delhi.

Brounen, D., de Jong, A., \& Koedijk, K. (2004). Corporate finance in Europe: Confronting theory with practice. Financial Management, 33(4), 71-101.

Dhanani, A. (2005). Corporate dividend policy: the views of British financial 
managers. Journal of Business Finance

and Accounting, 32(1),1625-1671.

Gliner, J. A., \& Morgan, G. A. (2000).

Research methods in applied settings: an integrated approach to design \& analysis,Morwah, NJ: Lawrence Erlbaum.

Gordon, M. (1959). Dividends, earnings, and stock prices. The review of economics and statistics, 41(2), 99- 108.

Graham, J., \& Harvey, C. (2001). The theory and practice of corporate finance: evidence from the field. Journal of Financial Economics, 60( 2-3), 87-243.

Harshapriya,W.G.R.(2016). The impact of dividend policy on share price volatility: Evidence from banking stocks in CSE. Staff studies: Central Bank of Sri Lanka, $16(1 \& 2), 27-68$.

Isa, M. (2008). Corporate finance practices in Malaysia. Capital markets review, 16(2), 53-73.

Lintner, J. (1956). Distribution of incomes of operations among dividends, retained earnings and taxes. The American Economic Review, 46(2), 97-113.

Lintner, J. (1962). Dividends, earnings, leverage, stock prices and supply of capital to corporation, The Review of Economics and Statistics, 44(3), 243269.

Miller, M. H., \& Modigliani, F. (1961). Dividend policy, growth and the valuation of shares. Journal of Business, 34(4), 411-433.

Panigrahi, S., \& Zainuddin, Y. (2015). Dividend policy decisions: theoretical views and relevant issues. Reports on economic and finance, 1(1), 43-58.

Pike, R., \& Neale, B. (2009). Corporate finance and investment decisions and strategies, 6th edn., Harlow: Pearson Prentice Hall.

Subramaniyam, R., \& Susela, D.S. (2010). Corporate governance and dividend policy in Malaysia. International Conference on Business and Economics Research 1, 200-207. Kuala Lumpur, Malaysia.

Verbeeten, F.H. M. (2006). Do organizations adopt sophisticated capital budgeting practices to deal with uncertainty in the investment decision? A research note. Management Accounting Research, 17(1),106-120. 